\title{
A QUESTÃO ELEITORAL NA IMPRENSA LIBERAL RIO-GRANDENSE DO SÉCULO XIX
}

Artur César Isaia*

Em 1878, D. Pedro II afasta os conservadores e chama os liberais, na pessoa de Sinimbú, para organizar novo ministério e realizar a decantada reforma eleitoral.

Os debates que se seguiram, no Parlamento e na imprensa política brasileira, são extremamente importantes para conhecermos os contornos do pensamento político dos partidos e dos homens públicos.

Sinimbú deveria encaminhar o processo de reforma dentro dos limites traçados pela coroa, isto é, a partir de lei ordinária. ${ }^{1}$

O projeto de Sinimbú elevava para $400 \$ 000$ de renda líquida anual o censo eleitoral, além da exclusão do voto do analfabeto. Em parte, o projeto Sinimbú não tocava: a elegibilidade dos acatólicos, daí o desentendimento com Silveira Martins, que se retira do Ministério da Fazenda, pois há muito que se tornara porta-voz dos interesses dos imigrantes alemães.

O projeto, apesar de haver sido aprovado pela Câmara Temporária, provocou enérgica oposição por parte da dissidência liberal, comandada por José Bonifácio, o Moço. Questōes como a elevação do censo (que contrariava não só o manifesto liberal de 1869 , como também a posição da bancada liberal do Senado que, em 1875 , manifestava-se pela sua diminuição), a exclusão dos analfabetos e a não elegibilidade dos acatólicos deram motivos a manifestações que claramente dão uma idéia do posicionamento da dissidência liberal na Câmara dos Deputados.

No Rio Grande do Sul, tanto o Partido Conservador como o Liberal manifestavam-se contrariamente, por motivos diferentes, é lógico, ao projeto de Sinimbú.

Enquanto o órgão do Partido Conservador temia os perigos de uma 
constituinte, mesmo que com poderes limitados, o Partido Liberal considerava traídos os princípios do partido. O ponto de referência nas discussões era o da elegibilidade dos acatólicos (questão que aliás cindia o próprio Partido Liberal na Província).

Em um editorial de setembro de 1879 , assim $O$ Conservador atacava a proposta de reforma constitucional de Sinimbú:

"S. Excelência no governo tem o defeito de origem; é anciāo de idéias adiantadas e a experiência tem demonstrado que os avanços sempre ficam atrasados.",2

Em relação às pretensões de elegibilidade dos acatólicos, reclamadas pela zona colonial alemã, que tinha em Gaspar Martins seu mais combativo porta-voz, escrevia o órgão conservador, atacando, tanto os colonos alemães, quanto a Silveira Martins e denunciando:

“. . alguns estrangeiros que em vez de usarem do direito de petição . . a ao contrário, ligam-se aos estouvamentos de tribunos famigerados e nos ameaçam no interior de nossa casa, com a demulição do nosso objeto mais sagrado, que é a nossa constituição política." 3

Posição diametralmente oposta tinha a maioria liberal da província. Esta encerrava fileiras em torno de Silveira Martins que entendia que só a:

"instituição monárquica, os poderes que se reparte e distribui, as atribuiçóes do Estado, os direitos e as garantias dos cidadãos não se podem reformar pela lei ordinária, tudo o mais pode sê-lo e o deve ser pela própria conveniência na manutenção da própria constituição.", 4

O Partido Conservador mostrava-se peremptoriamente contrário às reformas reclamadas por Silveira Martins e capitalizava a preemência dada pelo chefe liberal ao assunto. Acusava os alemães de, com a conivência de Silveira Martins, conspirarem para instaurar a supremacia teutônica na província. Quando no auge da campanha pela elegibilidade dos acatólicos, Silveira Martins abandonou a pasta da fazenda, indisposto com Sinimbú, contrário àquela medida, escrevia $O$ Conservador que a demissão do chefe liberal rio-grandense acentuava mais a "Propaganda teutônica".

Outrossim, dizia ser a elegibilidade dos acatólicos uma mera desculpa 
para encobrir o verdadeiro interesse dos alemães: a supremacia "do elemento alemão na província." 5

$\mathrm{Na}$ verdade, não era apenas a pureza do texto constitucional que os conservadores defendiam ao oporem-se ao projeto defendido por Silveira Martins. Era a própria força e apoio desfrutados pelo partido Liberal na zona colonial alemã, o alvo dos ataques do órgão conservador.

Ao zelo conservador pelo "nosso objeto mais sagrado" opunham-se os liberais, na voz de Silveira Martins. Seu posicionamento revelava não só a vulnerabilidade da carta outorgada, como até mesmo discutia sua legitimidade. Isto está evidente no discurso de Silveira Martins, transcrito na Reforma, com grande destaque, no dia 4 de dezembro de 1880 .

"A Constituição, que muitos consideram como Arca Santa das liberdades públicas, não foi obra dos legitimos representantes de uma na ção que se constituia. Os representantes legitimos foram dissolvidos pelo canhão. A Carta constitucional não passa de uma carta constitucional, que representa o direito da força ..."6

Sendo assim, ao mostrar o caráter antidemocrático da Constituição e ao enumerar os itens, passíveis de serem reformulados por lei ordinária, o chefe liberal antecipava-se aos possíveis atacantes da elegibilidade dos acatólicos e da reforma eleitoral, cujos argumentos pudessem provir da intocabilidade do tex to constitucional.

De fato $O$ Mercantil transcreve um artigo de um jornal de São Paulo, $A$ Reação, no qual lia-se ser impossível harmonizar-se a elegibilidade dos acatólicos com o artigo 5 o da Constituição que declara ser a religião Católica Apostólica Romana a oficial do Estado. ${ }^{7}$

$\mathrm{O}$ jornal, que defendia a dissidência do partido liberal, assim manifestava-se a esse respeito:

“. . partindo do fato de ter a nossa constituiçāo politica escolhido a religiáo católica por religiâo de estado temos a prova da exclusão dos acatólicos à eleigão de deputado geral. Esta exclusão é um direito pré-estabelecido e aceito, pelos emigrantes acatólicos que se vêm domiciliar no Brasil. Fazer, portanto, manifestạ̧ōes acatólicas com estrangeiros e brasileiros de uma só raça, é ostentar uma influência ilegitima ...",8 
A magnitude da questão da elegibilidade dos acatólicos para o Partido Liberal é atestada na campanha política encetada, quando da eleição senatorial de novembro de 1879 . O referido pleito deveria preencher as vagas deixadas no Senado com a morte do Marquês do Herval e do Visconde do Rio Grande.

$O$ Diário de Pelotas, fiel à maioria liberal que reconhecia em Silveira Martins seu chefe, fechava claramente questão ao lado da Reforma de Porto Alegre. É assim que publica, em 14 de novembro de 1879, uma recomendação para que se apóiem apenas aos candidatos fiéis a causa da elegibilidade dos acatólicos.

"Em uma eleição em que não há adversários não se pode exigir o corpo eleitoral homogeneidade na votação. Todos aqueles que professarem o principio da elegibilidade dos acatólicos têm direito a pedir os sufrágios de seus concidadãos.

Da chapa organizada apenas entendemos que deva ser questão de honra do Partido Liberal sustentar os Srs. Conselheiros Gaspar Martins, Visconde de Pelotas e Dr. Florêncio de Abreu.

Todos os demais devem ficar sujeitos à apreciação do eleitorado ... Aceitam ou não desde já o principio da elegibilidade dos acatólicos? $O$ silêncio neste caso não importa um assentimento d̀ idéia, mas sim um subterfúgio capcioso para mais tarde poder-se fugir ao compromisso tatitamente contraido."

A guerra que a facção majoritária do Partido Liberal movia contra a ortodoxia católica, que, encastelada no art. 59 da Carta outorgada, tinha nos jesuítas os mais ferrenhos aliados, era comandada pela Reforma. Transcrevendo um artigo de Edmond Scherres ( $\mathrm{O}$ que é um jesuíta), o órgão oficial do partido mostrava claramente o caráter combativo da campanha que movia:

“. . é pelo elogio da obediência passiva que eles imaginam levantar um paradeiro a libertação da consciência e da razão nas sociedades.

E são esses homens que se propõem dirigir nossas mulheres e ser os mestres dos nossos filhos.

São tais eunucos que se julgam capazes de formar homens." 10 
A estrondosa campanha, que a ala "gasparista" majoritária moveu em defesa da elegibilidade dos acatólicos, fez cue, mesmo em um jornal fiel à dissidência Liberal, como o jornal do Comércio de Pelotas, movesse uma apressada manifestação favorável àquele assunto. É assim que, nos dias 23, 23 e 26 de novembro de 1879, o Jornal do Comércio pelotense, criticando o parecer do Conselho de Estado, manifestava-se favorável à elegibilidade dos acatólicos. Com as palabras abaixo, tentava o periódico pelotense salvar a candidatura de Luiz Flores, pai do Presidente de Província, da recomendação do Diário de Pelotas, que dias antes alertava ao eleitorado liberal para não votar em candidatos contrários à causa dos acatólicos.

" $O$ que devemos, sobretudo recear e evitar é a imobilidade de que nos ameaça a regiliâo do Estado, e o isolamento do conceito geral das naçôes de que nos ameaça a inelegibilidade dos acatólicos." 11

Além de defender a candidatura oficial, o Jornal do Comércio de Pelotas tentava nulificar a campanha que o jornal "gasparista" daquela cidade movia contra os candidatos que não se definiam sobre a questão do momento para o Partido Liberal: a elegibilidade dos acatólicos. É assim que se apressava em publicar uma carta do deputado Fernando Luiz Osório, herdeiro político de seu pai, o Marquês do Herval. A referida carta é acompanhada de cópia de uma missiva do Marquês do Herval dirigida ao tenentegeneral, Visconde de Pelotas.

$\mathrm{Na}$ carta, Fernando Osório mostrava-se como seguidor das idéias de seu pai, que, segundo a missiva anexa, jamais foi contra os direitos políticos dos acatólicos.

"Ambiciono honrar a sua memória e sustentar agora co-
mo no futuro a posição em que estou colocado pelo par-
tido que tem-me visto combatendo, embora fraco, na
vanguarda e ao lado dos mais dedicados, em prol dos di-
reitos dos meus compatriotas."12

$\mathrm{Na}$ carta do Marquês do Herval, na qual justifica sua permanência no gabinete Sinimbú, vista como contrária às idéias de Silveira Martins pela imprensa "gasparista", Osório, referindo-se a elegibilidade dos acatólicos, tenta uma saída política para o problema, afirmando: 
"Efetivamente eu via o principio justissimo de equiparar os a católicos aos demais cidadãos, no direito de entrar na Câmara, mas via também que sendo tâo dominuto o número deles neste caso, a medida teria um valor mais de teoria que de prática. Faltava-lhe o caraiter de urgente $e$ indeclinavel." 13

Posicionamento idêntico tinha o órgão do Partido Conservador que, apesar de dizer conhecer as reivindicaçōes dos acatólicos, manifestava-se peremptoriamente contra à preemência que o chefe liberal rio-grandense dava ao assunto.

Com essa campanha, tentava manter a ala majoritária do Partido Liberal, o precioso apoio político da zona colonial alemã. Assim, os integrantes continuavam nas fileiras liberais, dentro da tradicional posição de apoio a seus candidatos, em troca da obtenção de favores, conseguidos pela influência política de Silveira Martins, que continuava como chefe político de maior expressão.

A possibilidade aberta pela aliança gasparista aos de representatividade no parlamento do Império, deve ser vista nas suas limitaçōes. Quem eram os "brummer"? Exerceriam eles uma liderança realmente autêntica? De maneira alguma. Como observou Sandra Pesavento, os "Brummer":

“. . atuavam como uma elite politica e intelectualiza$d a$, que realizava a medição entre o Partido Liberal, controlado por pecuaristas, e o complexo mundo colonial! ( . . ) Atuavam mais pelo mecanismo da cooptação dos grupos dirigentes ao nivel regional." 14

Isso era uma decorrência lógica do sistema representativo imperante até 1889 , pois mesmo quando a elegibilidade dos acatólicos foi permitida, em 1881, a renda necessária para concorrer ao legislativo foi duplicada, impedindo o acesso total dos imigrantes aos cargos eletivos. Ficando restrita a elegibilidade a uma minoria (grandes comerciantes predominantemente); era natural a pouca vinculação dos "brummer" com o restante do mundo colonial.

Assim, podemos sentir o caráter elitista do Partido Liberal, mesmo quando defendia proposiçøes à primeira vista includentes, como a elegibilidade dos acatólicos. Unicamente, o que a elite liberal desejava era manter e aumentar a aliança gasparista com o mundo colonial, a fim de garantir uma sólida base que legitimasse seu predomínio na província. 
Karl Von Koseritz era um político que, apesar de atuar dentro das regras de subordinação do partido Liberal, apresentava propostas, muitas vezes discordantes com os interesses da elite colonial. $\mathrm{O}$ arrojo de suas posiçôes manifestadas na Gazeta de Porto Alegre e no Drutsche Zeitung divergia não só dos grandes comerciantes alemães, como também das idéias "oficiais" do partido a que se vinculava.

É o jornal de Koseritz que, apesar de ligado ao Partido Liberal, assim manifestava-se, quando do auge da luta do partido pela eleição direta:

“. . . a eleição direta por si só não é suficiente; é necessário que as luzes da instrução se difundam no povo e que haja nele melhor educação politica, mais interesse sério pelos assuntos politicos, mais opinião própria finalmente."

E corajosamente proclama:

"A eleição direta é uma burla, é um laço, é uma estupenda mistificação. Conservadores, liberais e até republicannos estão sendo empanados, acreditando que a situação do país vai melhorar, só porque se vai operar uma pequena alteração no cenário. Mas, os atores continuam os mesmos: a comédia há de ser a mesma." 15

Esta era uma voz que, momentaneamente, desafinava-se do discurso liberal. Contudo, essas colocaçōes não eram capazes de desfazer o tradicional apoio dado pelo jornal de Koseritz à aliança gasparista. Apenas mostram que a voz de Koseritz não era simplesmente a dos grandes comerciantes alemães cooptados. Como se pôde ver, por ocasião da Exposição TeutoBrasileira de 1881 , quando indispôs-se com o comércio alemão da capital ou quando opôs-se a um projeto que dava privilégios a Rhengantz para instalação de uma indústria têxtil, Koseritz estava longe de representar exclusivamente o grupo colonial dominante.

No tocante à temática eleitoral-representativa, a Gazeta de Porto Alegre também não se mostrava em perfeita concordância com o ideário defendido pelo Partido Liberal do Rio Grande do Sul.

Koseritz, em harmonia com a teoria dos fisiocratas, via na agricultura a principal fonte de riqueza. Por isso defendia os interesses dos pequenos agricultores imigrantes, orientando os mesmos, inclusive através de artigos em jornais, a cerca de técnicas agrícolas. ${ }^{16}$ Nada mais natural, portanto, do 
que defender uma ordenação política mais aberta.

No tocante à reformulação eleitoral, o posicionamento de seu jornal, a Gazeta de Porto Alegre, é bem elucidativo. Defendendo uma ordem institucional mais includente, fugia do conservadorismo liberal expresso na $R e$ forma e nos principais jornais liberais.

Posiçōes, como as abaixo transcritas, vão de encontro às idéias abraçadas pela folha de Koseritz:

“. . jamais imporemos ao nosso pais reformas para as quais não se acha preparado, e que não conquistaram as simpatias e as adesões populares.

$\vec{E}$ mil vezes preferivel a Conservação das forças existentes, a renová-las irrefletidamente; e muitas vezes a própria idéia da liberdade é sacrificada quando pensa-se em sã consciência trabalhar a seu favor." 17

Ao temor de se implantar reformas mais drásticas na ordem política brasileira, próprio do conservadorismo liberal rio-grandense do século XIX, opunham-se os interesses de uma ampla facção do mesmo partido, que se manifestava sobretudo no Deutsche Zeitung e na Gazeta de Porto Alegre. Era a grande maioria dos colonos imigrantes alemães, aqui radicados, representados pela imprensa ligada a Koseritz.

Por exemplo, em 1879, comentando o projeto de reforma eleitoral do Gabinete Sinimbú, diz:

“A proposta é raquitica e absolutamente insuficiente. Os maiores problemas de nossa atualidade, os econômicos, que se prendem d̀ produção, à imigração, e por conseguinte, à grande naturalização, assim como os religiosos (...) não foram contemplados no programa de reforma constitucional. (...) Por outro lado, acha-se de tal sorte comprometido o futuro econômico do pais, que se torna necessária uma reforma radical nas condiçôes de produção e esta só pode ser levada a efeito mediante as medidas que prendem d grande naturalização facultativa, eliminando do código fundamental as disposiçōes que impōem ao estrangeiro naturalizado, todo o ônus do cidadão, sem conceder-lhe também os seus direitos, equiparando-o civil e religiosamente com os cidadãos natos." 18 
O exercício total da cidadania, implícito na idéia de "grande naturalização", era defendido ardorosamente pela imprensa ligada a Koseritz. Dentro dessa perspectiva, defendia a abolição do censo eleitoral e, conseqüentemente, o livre acesso de todos os cidadãos aptos aos cargos eletivos.

A Gazeta de Porto Alegre, fiel às idéias de Koseritz, apresenta um posicionamento totalmente inovador quanto à temática eleitoral - representativa, chegando mesmo, para espanto de liberais e conservadores, propor o direito de voto às mulheres.

A adoção do sufrágio universal é preconizada pela Gazeta de Porto Alegre nos seguintes termos:

"Do direito de votar só devem ser excluidos os menores, os cativos, os que vivem da caridade pública, os que estão no rol dos culpados e last not least - os analfabetos." 19

Condenando o voto censitário opinava:

"A sã politica manda hoje unir e fundir as diferentes classes sociais, em vez de dividi-las, umas com as outras. Reconhece-se hoje geralmente, que é pouco racional tornar os direitos politicos dependentes das posses de cada um, porque por esse meio colocar-se-ia o centro de gravidade da vida da nação naquelas classes que são mais influidas pelo egoismo, pela ambição de posses, pela avareza e pela reserva. . ."

Diz que é absurdo renegar a democracia em favor da plutocracia,
“. . e é entretanto o que se dava, desde que as posses do cidadão formem o último critérium para o exercicio dos direitos politicos. (...) Destarte chegamos a con- clusão, que adotando-se a eleição direta, deve ser abolido o censo, como o foi em França, na Suiça, na Itália, no Império alemão e nos EEUU." 20

A tendência mais "popular" do Jornal de Koseritz transparece em toda a discussão sobre a reforma eleitoral, que ocupa suas páginas, sobretudo, nos anos de 1879 e 1880 . Ao falar sobre as vantagens da eleição direta, faz uma claríssima distinção entre "povo" e "burguesia", posicionando-se de maneira decidida em favor de uma ordem institucional em que prevalecessem os interesses da primeira categoria. 
"A eleição direta estabelece relaçôes de imediata confiança entre o votante e o representante ao passo que na indireta tem essa confiança medianeiros nas pessoas dos eleitores, que freqüentemente se julgam livres de compromissos e procedem segundo suas próprias inspirações (...) onde ha eleição direta, o povo toma maior parte na vida politica e interessa-se mais pela eleigão do que havendo eleição por dois graus. (. . .) A eleição direta coloca o centro de gravidaie no quarto estado (na grande massa do povo) ao passo que a eleição indireta favorece ao terceiro estado (o que na Europa se chama burguesia), do qual são oriundos os eleitores. "21

O posicionamento do Jornal de Koseritz, vinculado à imprensa liberal rio-grandense do último quartel do século XIX, apresentava, portanto, peculiaridades bem marcantes em relação à posição "oficial" do mesmo partido, representada pela "Reforma". Como harmonizar a tendência "popular", "à la Rousseau", exposta acima, com as posiçб̄es claramente elitistas do Partido Liberal Rio-Grandense ou dos "brummer" cooptados pelos latifundiários? Isso mostra-nos claramente que as propostas do Partido Liberal de reformulação do Regime Eleitoral do Império não formavam um todo acorde e monolítico. Expressão inconteste da diversidade de forças sociais inseridas na "aliança gasparista", a Gazeta de Porto Alegre não pôde diluir-se nas propostas do grupo regionalmente hegemônico e senhor da mesma aliança: a elite latifundiária.

É óbvio que a "posição oficial" do Partido Liberal, como portavoz dos interesses da camada senhorial ${ }^{22}$, mostrará uma frontal incongruência com o posicionamento da Gazeta de Porto Alegre, onde Koseritz propunha uma ordem mais includente, na direção dos imigrantes pequenos proprietários.

Além de, como vimos, defender o sufrágio universal, condena a elite bacharelesca, que, como porta-voz da camada hemegônica, domina o Parlamento do Império.

“Hoje, que o parlamento pertence aos bacharéis, temos ali exercicios retóricos de todas as qualidades, a eloqüencia acadêmica com todos os seus atavios da frase: e só por excessão de regra ouvimos, uma ou outra vez, levantar-se a voz do bom senso, advogando com os interesses reais do pais." 
E o que seriam os interesses "reais do país" para a folha de Koseritz? Logicamente seriam os ligados "à produção".

"Ainda na presente legislatura vemos, que em 122 deputados há nada menos do que 114 bacharéis (... ). O comércio, a lavoura, a indústria e as artes não têm representação."23

A Gazeta de Porto Alegre, outrossim, pugnava pela total igualdade política entre os cidadãos. O sufrágio universal deveria corresponder a uma legítima equiparação no direito de elegibilidade. Com isso, vai frontalmente de encontro ao espírito da reforma de 1881, que tornou mais excludente ainda o nosso regime eleitoral.

Opondo-se à posição oficial do partido, que teimava em defender o critério censitário para votante e, sobretudo, para concorrer aos cargos eletivos, assim a Gazeta de Porto Alegre resume sua postura a respeito:

"Elegibilidade de todos quantos podem ser votantes, sem outra restrição além da relativa à idade.

Principalmente deve ser abolida a disposigão que exige que o deputado e o senador professem 'religião católi$c a^{\prime \prime},{ }^{24}$

A peculiaridade do posicionamento do jornal de Koseritz atinge, num ponto, feições completamente inovadoras para os padrōes da época. Em uma sociedade rigidamente patriarcal e com uma ordenação jurídicoinstitucional marcada pelo elitismo, a Gazeta de Porto Alegre, além de preconizar uma ordem social mais aberta, chega ao ponto de propor o direito de voto às mulheres.

Enfileirando-se na questão, com o posicionamento de Stuart Mill, condena a discordância entre os direitos civis que a mulher tinha e os políticos que lhe eram negados.

Frisa ele (Stuart Mill) a grande contradição que há em admitir-se à mulher os direitos civis, deixando-a negociar, adquirir propriedades, etc., e privando-a, entretanto, da influência sobre a legislação, cujos efeitos interessam tanto a ela como ao homem.

Traçando um paralelo entre a eventualidade de um terceiro reinado, tendo como titular uma mulher e a exclusão feminina dos direitos políticos, pergunta: 
"Se uma senhora pode reinar, governar e administrar, porque hão de as outras suas patricias não exercer direitos politicos? (. . .) a mulher que nasce nos degraus de um trono nẫo é feita de matéria diversa das outras; se ela pode governar, porque não hão de ao menos votar as suas irmãs do povo?"25

Essas colocações, apesar de chocarem-se com as idéias defendidas pela Reforma, não provocaram uma réplica explícita pelo órgão oficial do Partido Liberal. A aliança gasparista era fundamental para a agremiaçao liberal, daí o desinteresse em polenizar com a folha de Koseritz. A oposição radical às idéias da Gazeta de Porto Alegre seria obra da imprensa "florista" ligada à dissidência liberal que combatia Silveira Martins e, portanto, a aliança gasparista.

Defendendo o voto direto, mas censitário, dizia a Folha ligada ao Presidente da Província:

“. . conquanto se afigura contrário d̀ liberdade, é todavia a melhor garantia dela, porque a ação do governo sobre o eleitor censitário, será tanto pelo menos eficaz quanto mais independente for ele pelos seus recursos particulares, o que não acontece com o sufrágio universal, sobre cuja massa o suborno e a compressấo influem...,"26

Opondo-se frontalmente ao "sufrágio direto sobre a ilustração e não pelo censo" defendido pela Gazeta, o Mercantil punha em dúvida a aplicabilidade da idéia defendida pela folha de Koseritz com essas palavras:

"A instrução pública, por exemplo, podera ser na pro-" vincia decentemente qualificada, Máquina politica e prêmio de colisões partidárias, é um cancro (. . .) Desde a escola normal até o último professor, com rarissimas excessões, têm uma fisionomia especial, um tipo indecente e desaforado, que desde os bancos rudimentares do ensino, imprime na mocidade o desprezo por tudo quanto é sublime, injuria o berço, desrespeita a tumba." 
Igualmente suspeita da justiça no sentido de bem desempenhar suas funçōes na qualificação dos eleitores:

"Na justiça sobre já se ter nomeado por juizes individuos analfabetos, provocadores convencidos, promotores inábeis (...) ainda, de mais a mais, se conserva em cargos policiais os mais ousados assassinos, e outros destes se protege pela imprensa caluniando os ofendidos." 27

Igualmente, a folha "florista" ataca as idéias da Gazeta referente a um ponto capital: a extensão do sufrágio à mulher. Quanto a isso, o Mercantil chega a denunciar que a folha de Koseritz pregava o "Comunismo", pois o sufrágio feminino colaboraria para a dissolução da ordem familiar. É inconcebível o direito de voto à mulher, segundo o Mercantil, pois:

" $O$ bom senso indica que assim como o Estado representa as familias politica e civilmente falando, também a familia deve ter um representante exclusivo em suas relaçōes com o mesmo Estado. Para semelhante fim a familia deve ter um chefe com todos os poderes lega is conferidos pela lei e esse chefe superior somente nesse ponto, devera ser escolhido, segundo a sua missão natural, entre marido e mulher."

E após concluir que ao marido, cabeça do casal, concebe representar a família em relação ao Estado, refere-se à mulher nestes termos:

"Ela, pois, é o ente predestinado para subjugar a serpente da sabedoria, que biblicamente é chamada árvore da ciência do bem e do mal, não pleiteando eleiçôes nas praças públicas, expostas assim aos sentidos licenciosos de quantos a desejam macular em troca de um voto, mas no lar, e com o exemplo inspirando a quem a rodeia nesse culto, que só ela merece.,"28

Quanto ao posicionamento da folha de Koseritz, que defendia uma ampliação no direito de votar e ser eleito, o mesmo parece ia-se compondo, lentamente, com o conservadorismo liberal das últimas décadas do século XIX. Que diferença entre o posicionamento às vésperas da reforma eleitoral de 1881 e o exposto nas últimas décadas da monarquia. O posicionamento das folhas de Koseritz parece ter sofrido uma "acomodação" às 
idéias dominantes no partido. Incapaz de encabeçar uma proposta que contestasse à ordem liberal, permanecendo no partido e ao mesmo tempo impossibilitado por motivos ideológicos (Koseritz permanece monarquista e acreditava que a coroa pudesse levar adiante todas as reformas pretendidas pelo país) ${ }^{29}$ de militar no PRR, o posicionamento do jornal de Koseritz parece ter sido obrigado a abdicar do "radicalismo" do passado em nome da comunhão liberal e da eterna aliança gasparista.

O mesmo Koseritz, que em 1880 defendia o sufrágio universal com a única exclusão dos analfabetos e plena condição de elegibilidade a todos qua nto pudessem votar, proclama oito anos após no Deutsch Zeitung:

"Não concordamos com o sufrágio universal; desejamos que se extenda o direito de voto até onde for possivel (...) quem pagar um qualquer imposto ao Estado, d provincia ou ao municipio deve ser eleitor, desde que saiba ler e escrever. Mas jamais concordaremos com a comunhão no direito de eleitor, dum proletariado sem propriedade de qualquer espécie e pouco afeita ao trabalho porque o contrário levaria o pais ao dominio brutal das massas que só têm interesse na destruição do que existe, sem noção justa da natureza do Estado juridico e dos deveres de cidadão." 30

Anteriormente, durante a "fase exaltada" de Koseritz, jamais a $R e$ forma reproduziu em suas páginas as colocações do Deustche Zeitung ou da Gazeta de Porto Alegre acerca da necessidade de um regime representativo mais aberto, ou suas críticas acerca do elitismo do referido regime.

Por outro lado, a análise da evolução do posicionamento da folha de Koseritz, sobre a problemática representativa, evidencia a verdadeira origem de sua postura. Representando os interesses da zona colonial alema em sua aliança com o gasparismo (notadamente, como vimos do pequeno proprietário), as reformas pretendidas estavam muito mais inseridas no universo ideológico defendido pela oligarquia liberal do que pelo "jacobinismo republicano". É dentro dessa perspectiva que devemos analisar o trânsito ocorrido no posicionamento de Koseritz, da "afoiteza" dos primeiros anos à acomodação final ao status quo liberal. Quer dizer, da busca pela criação de um espaço político, maior para o grupo que representava (na aliança gasparista, é claro), à constatação da impossibilidade de aprofundar propostas não inseridas no universo ideológico, consentido pela fraçâo dominante na referida aliança. 
A imprensa do Partido Liberal, representada pela Reforma, mais os periódicos do interior que a apoiavam, logicamente cerrava fileiras em torno do mais avalizado porta-voz liberal do Rio Grande do Sul: Gaspar Silveira Martins. É ele que, em discurso na Câmara dos Deputados a 6 de junho de 1879 , proclama:

"Se o voto, pois, é um direito político, é claro que a sociedade que o confere tem o direito de regulamentá-to. $\hat{E}$ assim que a sociedade tem um fim. O fim de uma deve ser o fim de toda a sociedade politica: é o desenvolvimento físico, moral e intelectual dos cidadãos e, para garantia desse fim ela tem direito de criar os meios que a levam, pouco a pouco, a esse destino.",31

E qual a maneira proposta pela imprensa "oficial" do partido Liberal, a fim de regulamentar o direito do voto? Os freqüentes apelos, no sentido de "procurar estender quanto possível" o direito de voto, revelam-nos uma preocupação eminentemente conservadora. Nessa perspectiva, ao mesmo tempo que a imprensa liberal procura compor-se com a opinião pública, (a questão eleitoral não era mais, como vemos, uma questão partidária), mostra-se incapaz de propor alternativas, onde a entidade "povo", mesmo que somente a nível de discurso, gozasse as prerrogativas do sistema representativo. A imprensa oficial do Partido Liberal permanece, assim, fiel às tradiçбes monárquicas. Sendo a representatividade restrita à elite uma característica peculiar a Monarquia brasileira, desempenhando uma função importantíssima no domínio do aparelho de Estado pela elite escravista, explica-se o posicionamento da imprensa liberal rio-grandense. A nossa elite, na dupla posição de classe hegemônica a nível regional e preterida do mando político a nível nacional, referendava, conseqüentemente, a postura da fração diretamente vinculada ao trono e ciosa da centralização.

Mesmo quando prejudicados pelo expediente usual das dissoluçбes da Câmara, era com a máxima moderação que a imprensa oficial do Partido Liberal posicionava-se. A pessoa do Imperador e as instituiçбes monárquicas eram poupadas ao máximo, concentrando toda a sua ira nos adversários. Um exemplo claro disso foi a dissolução da Câmara de maioria liberal em agosto de 1885. Nessa ocasiao, assim lemos na Reforma:

“Acatamos o ato do monarca, mas não deixamos de reconhecer que esse ato foi conseguido por manobras $e$ conluios inqualificaveis. Estão, pois os conservadores senhores ditatoriais do poder e dos cofres da nação. Podem 
fazer o que bem thes pareça e nẫo faltarão atos de violência, reação desenfreada, escandalosa intervenção nas eleiçôes com o fim de falsear-se a opinião do pais real, arranjando uma maioria que lhes garanta a duração do seu dominio." 32

Portanto, o cerne da questão, que levava às dissoluçб̄es e, conseqüentemente, à convocação de novas eleições, onde imperavam os expedientes de compressão, não é atacado. Por outro lado, a violência eleitoral, as perseguiçōes e demais expedientes são vistos desvinculados de um todo institucional maior. São apenas tratados como fatores inerentes à prática política dos adversários. Não atacam diretamente o arcabouço institucional que tolerava tais expedientes de que também se valiam na "confecção" de câmaras unânimes.

Além de pessoalizar os motivos que levavam às práticas de compreensão e cabala eleitoral, chegavam ao cúmulo de "desconhecer" momentaneamente as eleições encomendadas pelo Rio de Janeiro, na vida política da província. Quando da administração do Barão de Lucena, protestando contra a exibição de força armada às vésperas do pleito eleitoral, escre a Reforma:

"O Senhor desembargador Henrique Pereira de Lucena é nortista. Habituado ao sistema do governo pleitear as eleiçōes do norte do Império, pretende aplicá-lo no RS. Entre nós esta ridicula e indigna ostentação de forma armada, longe de abater os espiritos, os impaciente e irrita. Desde já o Partido Liberal o torna responsável por todo e qualquer desastre que sobrevenha no pleito eleitoral do dia 15 de janeiro." 33

Portanto, era o presidente da província o elemento responsável pela "implantação" do "sistema de governo pleitear as eleiçбes" no Rio Grande do Sul, na opinião da imprensa oficial do Partido Liberal. Tudo existia na ótica liberal, desvinculado de uma estrutura maior, ao sabor das individualidades. Cômoda posição para uma agremiação que, no poder, utilizava os mesmos expedientes.

A imprensa oficial do Partido Liberal parece fazer questão de não ver que se era possível à situação conservadora organizar um aparato policialesco, como integrante da máquina eleitoral, era porque havia pré-condiçōes institucionais capazes de conviver com semelhantes práticas e tolerá-las. Contudo, a crítica faz-se apenas ao "insensato Dr. Miguel Barcelos" e ao 
"hipócrita Sr. Lucena ..."

Mais incisivo na sua crítica contra o expediente das dissoluções usuais que tinha, momentaneamente, prejudicado o Partido Liberal, era $A$ Resistência órgão liberal de São Gabriel. Este periódico, comentando os sucessos que culminaram com a subida do ministério conservador, conseqüentemente, com a nomeação de um presidente de província do mesmo partido, diz:

\begin{abstract}
"Quando em todo o mundo civilizado os reis sofrem os rudes golpes do parlamentarismo moderno, e executamlhe as ordens, por serem ditadas pela nagăo quando o regime democrático triunfante firma o principio de que a soberania reside no povo, e que o rei é simples instrumento dela - sobressalta a reação e o fato de que só temos rei para obstar o desenvolvimento liberal do pais, imposto pela constituiçâ, pelas idéias do século e, mais que tudo, pela vontade nacional, livre e legitimamente manifestada." 34
\end{abstract}

Embora o periódico liberal gabrielense apresente uma crítica direta e mordaz à pessoa do imperante, que "substituía-se à própria nação", mostra-se tal qual o órgão oficial do Partido Liberal no RS, elitista e conservador. Assim, o "desenvolvimento liberal do país" atacado pelo Imperador era ditado pela vontade nacional. Se essa vontade nacional era identificada como "povo", parece desconhecer o periódico liberal que o nosso corpo eleitoral não ultrapassava um e meio por cento da população total do país. Por outro lado, a constatação da filha liberal de que a expressão da vontade nacional, que tinha feito uma câmara liberal dissolvida, dera-se de maneira "livre" e "legítima", está perfeitamente acomodada à ideologia do conservadorismo liberal. Na verdade, opinam os liberais que o nosso regime representativo é bom e o que dificulta a plena viabilização da "vontade nacional" é a fuga dos princípios do parlamentarismo, tão caros ao Partido Liberal. Assim, o regime representativo regenerado pela lei eleitoral de 1881 era satisfatório, apenas a intervenção do poder moderador é que impossibilitava a livre expressão da vontade "popular". Era a proposta liberal que pregava um Estado ño intervencionista no terreno econômico e um executivo dócil às prerrogativas do parlamento, no qual, prioritariamente, fosse ouvida a Câmara dos Deputados. Elucidativo a esse respeito é o discurso de Gaspar Silveira Martins pronunciado a 21 de abril de $1885 . .^{35}$ No pronunciamento, o tribuno gaúcho, fiel intérprete do pensamento liberal rio-grandense, opinava que o Senado, por ser a Corporação política de pri- 
meira ordem, não pode deixar de fazer política. Contudo, Silveira Martins nega-the a faculdade de desfazer ministérios. $\mathrm{O}$ orador no discurso parece representar bem a cautela com que o Partido Liberal tratava o assunto, resguardando a pessoa do Imperador. O que urge para Silveira Martins é a existência de ministérios fortes, apoiados em maiorias na Câmara Temporária. Assim, indiretamente ataca a intervenção do monarca, que, com o apoio da corporação vitalícia, efetivara a subida do Ministério Cotegipe.

$\hat{E}$ a continuação da proposta que, cinco anos antes, quando das discussões sobre a reformulação do regime elitoral, apresentava o Partido Liberal, pela sua imprensa oficial, na província.

"De nada vale que o parlamento esteja cercado de uma soma enorme de garantias, quando o executivo, jogando com a influência, corrige o pensamento da lei, fazendo representar o pais por deputados humildes e dóceis à sua vontade e caprichos. "36

As palavras acima foram publicadas pela Reforma, numa época em que pregava a "regeneração" dos costumes políticos, com a doação do voto direto e censitário. O Parlamentarismo é visto, nesta ocasião, como a "Garantia da verdade do sistema representativo que nos rege". 37

Portanto, as coordenadas básicas da proposta política liberal, onde se articulavam: parlamentarismo e representatividade restrita à elite, que persistem até o fim do Império, apresentam-se clara e inequivocamente já nas propostas de reformulação do regime eleitoral.

Com as reformas propostas pelo Partido Liberal: eligibilidade dos acatólicos, voto direto e censitário, diminuição no censo, satisfazia-se plenamente a imprensa oficial do Partido Liberal do Rio Grande do Sul. Apenas com essas reformas institucionais, esperava o Partido Liberal ter encontrado a panacéia ideal para resolução dos problemas que afligiam o Brasil.

"Com o novo regime eleitoral devemos esperar todos os proveitos para a nossa educação politica e uma verdadeira representação nacional. Com a elevação do nivel politico e com um parlamento saido do seio da nação conseguiremos elevar este grande império d̀ posição que ele deve ocupar no quadro das naçôes civilizadas.,"38

Este posicionamento tinha a oposição não só dos conservadores e republicanos, como também de uma fração da imprensa liberal na província (a ligada a Koseritz que, pelo menos nessa época, propunha mudanças mais 
profundas no intento de regenerar a vida política nacional).

Os republicanos pugnavam pelo sufrágio universal, endossando o manifesto de 1870 que proclamava:

"A soberania nacional só, pode existir em uma nação
cujo parlamento, eleito pela participação de todos os ci-
dadãos tenha a suprema direção e pronuncie a última pa-
lavra nos públicos negócios." 39

Já os conservadores, que se apresentavam como defensores da ordem e das prerrogativas do senado, acenando com os princípios do Visconde do Rio Branco "ordem com liberdade, estabilidade com progresso", repudiavam a proposta liberal. Embora vissem, na eleição direta, o ". . . centro e base de todas as reformas, e para qual o espírito público está preparado por uma longa luminosa e perseverante propaganda ...,"40

Não concordavam com a baixa no censo eleitoral, que na sua opinião equivalia à adoção do sufrágio universal. Seu posicionamento pode ser acompanhado pela imprensa conservadora da capital e do interior. É de um órgão do Rio Grande, na época fiel aos conservadores, as palavras abaixo:

"Da eleigão primária, portanto, procedem todos os vicios da urna. Raras vezes na secundaria se reproduzem os seus escandalos."

A raiz do problema era detectada no baixo censo:

"Quem entre nós, até o escravo alugado, não ganha por ano mais de $100 \$ 000$, já traduzido pela lei de $1876 \mathrm{em}$ $200 \$$ ? Não equivale este fato ao sufrágio universal? (. . .)

Censo elevado e provado com documentos que mostrem a profissão e a renda; qualificação feita sobre requerimentos dos próprios que desejem nela incluir-se (...)

O que não for isto, tornar-se-á mesmo maior calamidade e maior falseamento da eleição, quando ela seja direta. Antes, então, continue o atual sistema de dois graus."41

Era, portanto, a voz da agremiação conservadora, que o Mercantil identificava como:

"o elemento censitário (...) que representa a ordem com direito a ela, porque composto em sua maioria de 
proprietários, capitalistas e industraisi, tem tudo a perder com as revoluçōes... .,42

Entre a proposta do elemento censitário (Partido Conservador) e a de sufrágio generalizado proposto pelos Republicanos, os liberais adotavam uma postura cautelosa. Ao mesmo tempo em que proclamavam que: "O Brasil precisa de reformas, porque o povo quer ver alargada a esfera de seus direitos ... ${ }^{, 43}$, diziam que o voto era:

“. . um direito que deve ser exercido conscientemente. Ele representa o pensamento, a vontade, a ação fiscalizadora do cidadão. É, portanto, uma garantia - e dela usará só quem o puder e quiser." 44

Portanto, ao mesmo tempo que; fiel ao espírito do século, propunham o alargamento do voto, punham restriçōes à adoção do sufrágio plenamente generalizado.

Propunha a imprensa oficial do Partido Liberal, quando das discussōes sobre a reforma eleitoral, que antecederam a lei Saraiva, o seguinte critério para a realização da proposta do partido: a reforma eleitoral e demais itens do programa LIBERAL deveriam levar em conta o estado sócio-cultural do país, e a partir daí estudar os meios de compatibilizá-las com a realidade. Era contra os "princípios abstratos" de democracia, propostos pelo Partido Republicano, que poderiam conduzir o país ao caos e à ditadura:

"Não é uma larga distribuição do direito de voto que poderá criar uma verdadeira representação da vontade nacional, assim como não pode assegurar aquele resultado o estabelecimento de uma oligarquia de privilégio".

Dizia ser um "falso liberalismo" o discurso que via a legitimidade do regime político diretamente proporcional ao número de eleitores. Chamava de "declamação utopista".

“. . aquela que dá largas ao direito de voto, estendendoo a todos os individuos que tem atingido a uma determinada idade e restringindo as condiçōes necessárias para o uso e gozo dos direitos políticos." 45 
A imprensa oficial do Partido Liberal via o sufrágio universal em completa desarmonia com a realidade social brasileira.

"Falamos no Brasil, cujo desenvolvimento intelectual estó ainda embrionário (... ) não somos bastante ilustrados para que o nivel social tenha subido a um alto grau (...) Com o sufrágio universal (...) entronizariamos no pais o dominio do imprevisto, porque a massa popular nāo está habituada a intervir na marcha dos negócios públicos. Teríamos de ver mistificada, pela realização de um principio reconhecidamente liberal, a soberania popular". 46

O Partido Liberal, portanto, apesar de ver no sufrágio universal "o grande pensamento político da escola liberal", ${ }^{47}$ manifestava-se contrário ao mesmo devido à situação sócio-cultural brasileira.

Era a ideologia liberal, que pregava reformas não de maneira abrupta. Que fugia ao espectro da convulsão social, defendendo a ordem oligárquica dentro dos princípios do "liberalismo romântico." Segundo Ieda Gutfriend, os liberais exposavam uma ideologia que "conciliava, transigia, negociava", pretendendo reformas "através de contínua evolução e não de modificaçб̋es bruscas ou revolucionárias. Seu lema era: Deixar fazer, deixar passar." 48

Portanto, mais do que nunca, no tocante ao sufrágio universal, a imprensa liberal rio-grandense tentava conciliar as propostas sócio-políticas do século XIX, nas quais se dá a ascenção gradativa da reivindicação participatória, com a ideologia norteadora do partido, defensora de uma ordem excludente.

O sufrágio universal e a total equiparação nas condições de elegibilidade dos cidadãos eram projetados para um futuro longínquo. Antes seria necessário uma ampla e demorada cruzada em prol de uma educação geral. Enquanto o nível cultural do povo não estivesse elevado, o censo eleitoral teria uma missão histórica a cumprir. $\mathrm{O}$ censo funcionava como uma garantia capaz de resguardar a liberdade, além de tutelar a própria soberania popular.

Assim, ao mesmo tempo que a folha oficial do Partido Liberal na província diz que: "A vida do país reside no povo", preconiza que "se moralize essa força, para que ela ofereça garantias . .." 49

Para a realidade brasileira marcada pelo baixo nível sócio-cultural e pela falta de tradiçбes no tocante ao pleno exercícios da soberania, era o censo necessário, pois: 


\begin{abstract}
"Em uma nação de sufrágio restrito põe-se a garantia no cènso, na propriedade, no pequeno número de eleitores, em uma nação de sufrágio universal, não há destas precauçōes exteriores (. . . ) na alma do eleitor reside a garantia, é portanto esta alma que há mister esclarecer $e$ moralizar." 50
\end{abstract}

Portanto, no estágio em que se encontrava a população brasileira, era inadmissível para a imprensa liberal a instauração do sufrágio universal, proposto pelos republicanos.

O sufrágio universal era condenado pelos liberais, portanto, não de maneira absoluta, mas dentro de uma perspectiva relativa, que o contrapunha à realidade brasileira. Contudo, não deixavam de mostrar o seu ceticismo quanto a ser o sufrágio universal um fator de progresso e um aval das liberdades.

Negando a eficácia que a propaganda republicana e o espírito do século propagavam como inerentes ao sufrágio generalizado, esforçava-se a imprensa liberal em condenar o alargamento do voto e, conseqüentemente, o do acesso à representatividade parlamentar. Contra isso chocavam-se as propostas que pugnavam por uma ordem política mais includente. A um só tempo, contestavam a importância dada pelos republicanos à democratização do voto e viam-no "como a suprema salvação da sociedade." 51

\title{
NOTAS
}

${ }^{1}$ Nos Conselhos deixados à Princesa Isabel em 1871, assim referia-se D. Pedro II sobre o assunto reforma eleitoral: "Instam alguns pelas diretas, com maior ou menor franqueza, porém nada há mais grave do que uma reforma constitucional, sem o qual não se poderá fazer essa mudança do sistema das eleiçбes, embora conservem os eleitores indiretos a par da direta". Citado por HOLLANDA, Sergio Buarque de. História geral da civilizaçáo brasileira. Rio de Janeiro, Difel, 1977, v. 7.

${ }^{2}$ Editorial. $O$ conservador, 28 set. 1879 , p. 1.

${ }^{3}$ Id., ibid., 23 set., 1879 , p. 1.

${ }^{4}$ Reforma eleitoral. $A$ Reforma, $4 / 12 / 1880$, p. 1.

${ }^{5}$ Editorial. $O$ Conservador, 30 set. 1879 , p. 1 .

${ }^{6}$ Reforma eleitoral. $A$ Reforma, 4/12/1880, p. 1.

${ }_{8}^{7}$ A elegibilidade dos acatólicos. Mercantil, 28/6/1880, p. 1.

${ }^{8}$ NOCH IMMER. Mercantil, 01/09/1879, p. 1. 
${ }^{9}$ Editorial. Diário de Pelotas, 14/1/1879, p. 1.

${ }^{10} \mathrm{O}$ que é um jesufta. A Reforma, 11/11/1879, p. 2.

11 A elegibilidade dos acatólicos e o parecer do Conselho de Estado. Jornal do Comércio, Pelotas, 6/11/1879, p. 4.

${ }^{12}$ Carta política. Idem, $28 / 10 / 1879$, p. 4.

${ }^{13}$ Id., ibid. .

${ }^{14}$ PESAVENTO, Sandra Jatahy. O imigrante na política rio-grandense. In: DACANAL, José H. I. \& GONZAGA, Sergius (org.). RS: imigração \& colonização. Porto Alegre, Mercado Aberto, 1980.

${ }^{15}$ Grande naturalização. Gazeta de Porto Alegre, Porto Alegre, (s.d.).

${ }^{16}$ Ver FLORES, Moacyr. "Resumo da economia nacional". In: Correio do Povo, Porto Alegre, Suplemento Letras \& Livros, 7/8/1982.

${ }^{17}$ Programa político. A Reforma, Porto Alegre, 5/5/1888, p. 1.

${ }^{18}$ A GAZETA de Porto Alegre. A Constituinte, Porto Alegre, 27/2/1879, p. 1.

${ }^{19}$ Sistemas eleitorais V. Gazeta de Porto Alegre, Porto Alegre, 22/1/1880, p. 1.

${ }^{20}$ Id., ibid. .

${ }^{21}$ Sistemas eleitorais VIIL Gazeta de Porto Alegre, Porto Alegre, 27/1/1880, p. 1.

${ }^{22}$ A utilização do termo "Camada Senhorial", para configurar a elite hegemônica no RS, durante o século XIX, é usada na acepção que the empresta Fernando Henrique Cardoso. Assim, não se trata de uma camada "que se formou à base dos direitos de senhorio e muito menos como uma camada feudal". Os senhores, no RS, como no Brasil, eram "empreendedores econômicos. O uso do termo serve para caracterizar o tipo social que, alóm de chefe de famńlia e proprietário de escravos, formou-se 'pelo frotalecimento do poder econômico dos chefes de parentela (DOMINUS) que conseguiram exercer influência ou dispor de posiçð̃es na ordem estatal". Ver CARDOSO, Fernando Henrique. Capitalismo e escraviddo no Brasil meridional. Rio de Janeiro, Paz e Terra, 1977, p. 158.

${ }^{23}$ Sistemas eleitorais VI. Gazeta de Porto Alegre, Porto Alegre, 23/01/1880, p. 1.

${ }^{24}$ Sistemas eleitorais XII. Idem, 7/2/1880, p. 1 .

${ }^{25}$ Sistemas eleitorais. Idem, 10/1/1880, p. 1.

${ }^{26}$ Atualidade. O Mercantil, Porto Alegre, 31/1/1880, p. 1.

${ }^{27}$ Id., ibid. .

${ }^{28}$ Id., ibid., $16 / 1 / 1880$, p. 1.

${ }^{29}$ Ver CARNEIRO, José Fernando. Karl Von Koseritz. Porto Alegre, I.E.L., 1959.

${ }^{30}$ A nova era. A Reforma, Porto Alegre, 8/6/1888, p. 1 .

${ }^{31}$ A REFORMA, Porto Alegre, 7/7/1879, p. 1.

${ }^{32}$ Crônica política. A Reforma, Porto Alegre, 28/8/1885, p. 1 .

${ }^{33}$ Ostentação da força armada. Idem, 3/10/1886, p. 1.

${ }^{34}$ Editorial. A Resistência, São Gabriel, 22/11/1885, p. 1.

${ }^{35}$ Ver $A$ Reforma de 3/5/1885, p. 1.

${ }^{36}$ Reforma eleitoral. Idem, $15 / 8 / 1880$, p. 1 .

${ }^{37}$ Id., ibid. .

${ }^{38}$ Id., ibid., 30/12/1880, p. 1.

${ }^{39}$ Manifesto republicano apud. MELO, Américo Brasiliense de Almeida e. Os programas dos partidos e o 2 ? império. Brasflia, Senado federal; Rio de Janeiro, Fundação Casa Rui Barbosa, 1979, p. 80.

${ }^{40}$ O CONSERVADOR. Manifesto da A ssembléia Provincial, Porto Alegre, 30/9/1879, 
p. 1 .

${ }^{41}$ EHO DO SUL. O projeto de reforma eleitoral do Sr. Saraiva. Rio Grande, 5/5/ 1880 , p. 1.

${ }^{42}$ O MERCANTIL, A tualidade, Porto Alegre, 31/1/1880, p. 1.

${ }^{43}$ Polftica liberal. A Reforma, Porto Alegre, 29/2/1884, p. 1.

${ }^{44}$ Trata-se de um discurso de Silveira Martins, pronunciado a 6/6/1879. Ver $A R e$ forma de $7 / 7 / 1879$, p. 1 .

${ }^{45}$ Reforma eleitoral. A Reforma, Porto Alegre, 17/8/1880, p. 1.

${ }^{46}$ Id., ibid. .

${ }^{47}$ Id., ibid. .

${ }^{48}$ GUTFRIEND, Ieda. RS: 1889-1896. A Proclamação da República e a reação liberal através da imprensa. Porto Alegre, PUCRS, Dissertação de Mestrado, 1979, p. 40.

${ }^{49}$ Reforma eleitoral. A Reforma, Porto Alegre, 19/8/1880, p. 1.

${ }^{50}$ Id., ibid. .

${ }^{51}$ Programa político. A Reforma, Porto Alegre, 3/5/1888, p. 1.

* Pontifícia Universidade Católica do RGS

Departamento de História

96620 Porto Alegre - RS. 